\title{
Enhancement of co-production of lutein and protein in Chlorella sorokiniana FZU60 using different bioprocess operation strategies
}

\author{
Ruijuan Ma1,2,3† , Zhen Zhang ${ }^{1,2,3 \dagger}$, Zhuzhen Tang ${ }^{1,2,3}$, Shih-Hsin Ho ${ }^{2,4}$, Xinguo Shi ${ }^{1,2,3}$, Lemian Liu1,2,3, \\ Youping $\mathrm{Xie}^{1,2,3^{*}}$ (I) and Jianfeng Chen ${ }^{1,2,3}$
}

\begin{abstract}
Co-production of multiple compounds is an efficient approach to enhance the economic feasibility of microalgaebased metabolites production. In this study, Chlorella sorokiniana FZU60 was cultivated under different bioprocess strategies to enhance the co-production of lutein and protein. Results showed that both lutein and protein content ( 7.72 and $538.06 \mathrm{mg} / \mathrm{g}$, respectively) were highest at the onset of nitrogen deficiency under batch cultivation. Semibatch III strategy, with 75\% microalgal culture replacement by fresh medium, obtained similar content, productivity, and yield of lutein and protein as batch cultivation, demonstrating that it can be used for stable and continuous production. Fed-batch II strategy, feeding with 1/3 modified BG11 medium, achieved super-high lutein and protein yield (28.81 and $1592.77 \mathrm{mg} / \mathrm{L}$, respectively), thus can be used for high-output production. Besides, two-stage strategy, combining light intensity shift and semi-batch cultivation, gained extremely high lutein and protein productivity (15.31 and $1080.41 \mathrm{mg} / \mathrm{L} /$ day, respectively), thereby is a good option for high-efficiency production. Moreover, the fed-batch II and two-stage strategy achieved high-quality lutein and protein, thus are promising for the co-production of lutein and protein in C. sorokiniana FZU60 for commercial application.
\end{abstract}

Keywords: Chlorella sorokiniana, Co-production, Lutein, Protein, Strategy

\section{Introduction}

Microalgae are deemed as potential feedstocks of many valuable products, such as proteins, pigments, lipids, and carbohydrates (Dixon and Wilken 2018). However, traditional microalgae cultivation is limited to a single product, leading to low production efficiency and high production cost. In recent years, co-production of multiple compounds from microalgae is regarded as an efficient way to enhance the economic feasibility (Ma et al. 2020a). To date, some microalgae have been used to coproduce multiple compounds, such as co-production of

*Correspondence: ypxie@fzu.edu.cn

${ }^{\dagger}$ Ruijuan Ma and Zhen Zhang contributed equally to this work

${ }^{1}$ Technical Innovation Service Platform for High Value and High Quality

Utilization of Marine Organism, Fuzhou University, Fuzhou 350108, China

Full list of author information is available at the end of the article eicosapentaenoic acid (EPA) and fucoxanthin in Chaetoceros gracilis (Tachihana et al. 2020), fucoxanthin and stearidonic acid (SDA) in Isochrysis zhangjiangensis (Li et al. 2019), protein and carotenoids in Dunaliella salina (Sui et al. 2019), and fatty acid and lutein in Chlamydomonas sp. JSC4 (Ma et al. 2020b).

Lutein is a carotenoid with human health benefits of preventing cancers, age-related macular degeneration (AMD), and cardiovascular diseases (Lin et al. 2015). It was reported that the global lutein market size was USD 288.41 million in 2019 , and is expected to USD 463.16 million by 2027 at a CAGR of $6.10 \%$ (Maximize Market Research PVT. LTD. 2020). Microalgae are considered as a promising alternative to the traditional lutein source (marigold) with the advantages of fast-growing, capacity of being industrially scaled up, and less susceptible to climatic, seasonal, and land limitations (Xie 
et al. 2021). However, microalgae-derived lutein has not been in commercial production due to the high production cost, which is mainly attributed to the relatively low lutein content (normally lower than 1\% DW) in microalgal biomass (Sun et al. 2016). Hence, co-production of other compounds could be an efficient way to add value to the lutein production, thus reducing the production cost.

Protein is one of the main components in microalgal cells, accounting for $6 \%$ to $70 \%$ of dry biomass $(50 \%$ for most microalgae) in dependence on the species and cultivation conditions (Levasseur et al. 2020). Moreover, the amino acid profile of microalgae perfectly matches the human requirements in FAO/WHO reference (Becker 2007; Kent et al. 2015). Thus, microalgal biomass arises as a potential source of high-quality non-animal protein (Geada et al. 2021). On the other hand, like lutein, protein is a primary metabolite, thereby can accumulate simultaneously with lutein (Ma et al. 2020a). Besides, protein and lutein are hydrosoluble and liposoluble molecules, respectively. These two types of molecules are easily separated, which is beneficial for extraction ( $\mathrm{Lu}$ et al. 2019; Soto-Sierra et al. 2020). Herein, protein can be used as a superior coproduct during microalgae-derived lutein production for improving economic feasibility. However, few attempts have been made to co-produce lutein and protein in microalgae.

In microalgae-based metabolites production, batch cultivation is the simplest culture mode. However, adverse conditions, such as nutrient and light limitation, occur with the extension of culture time, retarding cell growth and metabolites accumulation. For avoidance of these adverse circumstances, various cultivation strategies have been explored to improve metabolites production in microalgae. For example, semi-batch strategy, refreshing microalgal culture termly, can refrain microalgae from light limitation and sustain log phase growth with stable and continuous high productivity (Ho et al. 2014). Fed-batch strategy, providing nutrient to microalgal culture regularly, can avoid nutrient limitation in microalgal culture, thus obtaining high biomass concentration (Xie et al. 2013). In addition, two-stage strategy is normally performed to obtain enhanced cell growth in first stage and increased metabolite accumulation in second stage for achieving high production and productivity (Zhao et al. 2021). These bioprocess operation strategies would be efficient for the co-production of multiple products in microalgae. For instance, a two-stage strategy was used to enhance the co-production of protein and $\beta$-carotene in Dunaliella salina (Sui et al. 2019). Likewise, a semi-batch strategy was developed for increased co-production of fucoxanthin and docosahexaenoic acid (DHA) (Sun et al. 2019).
The green microalga Chlorella has been widely used for production of lutein (Khoo et al. 2021) or protein (Bin Azmi et al. 2021; Koyande et al. 2020) in recent years. However, the potential of co-production these two compounds from Chlorella needs to be evaluated. In this study, a lutein-enriched microalga Chlorella sorokiniana FZU60 (Xie et al. 2019a) was cultivated under the phototrophic conditions to investigate its potential for the co-production of lutein and protein. Further, different cultivation strategies, including semi-batch, fed-batch, and two-stage strategy, were carried out to enhance the co-production. The aim is to provide valuable information for improving the economic feasibility of lutein production by co-production of value-added byproducts.

\section{Materials and methods \\ Microalgal strain}

Chlorella sorokiniana FZU60, isolated from the coastal area of Fujian Province, China, was maintained in modified BG11 medium algal plate (deposited at $25^{\circ} \mathrm{C}$ ). For pre-culture, microalga was inoculated from the algal plate, and cultivated in 1-L photobioreactor with 1-L modified BG11 medium for 3 days. The seed culture was cultivated at $30{ }^{\circ} \mathrm{C}$ under the continuous fluorescent light of $250 \mu \mathrm{mol} / \mathrm{m}^{2} / \mathrm{s}$, agitated at $500 \mathrm{rpm}$, and aerated with $2.5 \% \mathrm{CO}_{2}$ at a rate of $0.15 \mathrm{vvm}$. The recipe of modified BG11 medium was as follows $(\mathrm{g} / \mathrm{L}): \mathrm{NaNO}_{3}$ $0.750, \mathrm{~K}_{2} \mathrm{HPO}_{4} 0.030, \mathrm{MgSO}_{4} \cdot 7 \mathrm{H}_{2} \mathrm{O} 0.075$, citric acid monohydrate $0.006, \mathrm{Na}_{2} \mathrm{CO}_{3} 0.020, \mathrm{CaCl}_{2} \cdot 2 \mathrm{H}_{2} \mathrm{O} 0.036$, ferric ammonium citrate 0.006, EDTA.2Na 0.001, trace elements $1 \mathrm{~mL}$. The composition of trace elements was as follows (g/L): $\mathrm{H}_{3} \mathrm{BO}_{3} 2.860, \mathrm{MnCl}_{2} \cdot 4 \mathrm{H}_{2} \mathrm{O} 1.810$, $\mathrm{ZnSO}_{4} \cdot 7 \mathrm{H}_{2} \mathrm{O} 0.222, \mathrm{Na}_{2} \mathrm{MoO}_{4} \cdot 2 \mathrm{H}_{2} \mathrm{O} 0.390, \mathrm{CuSO}_{4} \cdot 5 \mathrm{H}_{2} \mathrm{O}$ $0.079, \mathrm{Co}\left(\mathrm{NO}_{3}\right)_{2} \cdot 6 \mathrm{H}_{2} \mathrm{O} 0.049$.

\section{Experimental operation Batch cultivation}

The pre-cultured microalga was inoculated into fresh modified BG11 medium at an initial density of $65 \mathrm{mg} / \mathrm{L}$ and an initial nitrate concentration of $0.75 \mathrm{~g} / \mathrm{L}$. The cultures were cultivated at $35{ }^{\circ} \mathrm{C}$ under the continuous fluorescent light of $600 \mu \mathrm{mol} / \mathrm{m}^{2} / \mathrm{s}$, agitated at $500 \mathrm{rpm}$, and aerated with $2.5 \% \mathrm{CO}_{2}$ at a rate of $0.15 \mathrm{vvm}$. The microalgal culture was sampled every 0.5 day for the determination of biomass concentration, nitrogen concentration, lutein content, and protein content. The amino acid composition was measured when nitrogen was replete (0.5 days), $90 \%$ consumed (1.56 days), and completely depleted ( 2.5 days).

\section{Semi-batch cultivation strategy}

C. sorokiniana FZU60 was cultivated at the same conditions as batch cultivation until biomass concentration 
reached around $1.42 \mathrm{~g} / \mathrm{L}$. Then, $25 \%, 50 \%$ and $75 \%$ algal culture were replaced by the same volume of $1 \times$ modified BG11 medium for semi-batch I, II, and III strategy, respectively. The cultivation proceeded at the same conditions as before the replacement until $90 \%$ nitrogen was consumed again, and then a new round of replacement was conducted. The replacement was performed for five rounds. The microalgal culture was sampled at set time intervals for the measurement of biomass concentration, nitrogen concentration, lutein content, and protein content.

\section{Fed-batch cultivation strategy}

Two types of fed-batch cultivation strategies were carried out to further enhance lutein production. The cultivation conditions were the same as batch cultivation except as specifically described. For fed-batch I and II, concentrated nutrients were fed into microalgal culture to adjust the feeding concentration to be $0.25 \mathrm{~g} / \mathrm{L}$ sodium nitrate and $1 / 3$ modified BG11 medium, respectively, at the onset of nitrogen depletion ( $90 \%$ nitrogen was consumed). The cultivation lasted for 5.5 and 7.5 days for fed-batch I and II, respectively. Microalgal culture was sampled at set time intervals for the measurement of biomass concentration, nitrogen concentration, lutein content, and protein content.

\section{Two-stage cultivation strategy}

For the two-stage cultivation strategy, C. sorokiniana FZU60 was initially cultivated at the same conditions as batch cultivation except that the light intensity was set at $800 \mu \mathrm{mol} / \mathrm{m}^{2} / \mathrm{s}$, which was denoted as stage I. At the beginning of nitrogen depletion, $5 \%$ microalgal culture was inoculated into a 95\% fresh modified BG11 medium for the next round of stage $\mathrm{I}$. The remaining microalgal culture was fed with $1 \times$ modified BG11 medium and then cultivated under $250 \mu \mathrm{mol} / \mathrm{m}^{2} / \mathrm{s}$ fluorescent light until nitrogen depletion, which was denoted as stage II. This two-stage cultivation was repeated five times. The microalgal culture was sampled at an interval of 0.5 day for the determination of biomass and nitrogen concentration. Lutein and protein content were measured whenever nitrogen was at the onset of depletion.

\section{Analysis methods}

\section{Determination of growth and nitrate concentration}

A spectrophotometer (U-2001, Hitachi, Tokyo, Japan) was used to measure the optical density of $682 \mathrm{~nm}\left(\mathrm{OD}_{682}\right)$ of microalgal culture. Biomass concentration was determined by Eq. (1):

$$
y=0.2244 x-0.0045\left(R^{2}=0.9970\right),
$$

where $y$ and $x$ are biomass concentration and $\mathrm{OD}_{682}$, respectively.

The biomass productivity $\left(P_{\text {biomass }}\right)$ was determined by Eq. (2):

$$
P_{\text {biomass }}(\mathrm{g} / \mathrm{L} / \text { day })=\frac{X_{t}-X_{0}}{t},
$$

where $X_{t}$ is the biomass concentration $(\mathrm{g} / \mathrm{L})$ on t days, $X_{0}$ is the initial biomass concentration $(\mathrm{g} / \mathrm{L})$, and $t$ is culture time (day).

Nitrate concentration was measured as previously reported (Xie et al. 2019b). Briefly, $10 \mathrm{~mL}$ microalgal culture was filtered through a cellulose acetate filter with $0.22 \mu \mathrm{m}$ pore size. After properly diluted, the supernatant was measured at the optical density of $220 \mathrm{~nm}\left(\mathrm{OD}_{220}\right)$. The calculation of nitrate concentration was conducted by Eq. (3):

$$
y=22.63 x+0.0359\left(R^{2}=0.9990\right),
$$

where $y$ is nitrate concentration, and $x$ is $\mathrm{OD}_{220}$.

\section{Determination of lutein accumulation}

Extraction and quantification of carotenoids were performed as previously reported (Xie et al. 2019b). The lutein productivity $\left(P_{\text {lutein }}\right)$ and lutein yield $\left(Y_{\text {lutein }}\right)$ were determined by Eq. (4) and Eq. (5), respectively:

$$
\begin{aligned}
& P_{\text {lutein }}(\mathrm{mg} / \mathrm{L} / \text { day })=C_{\text {lutein }} \times P_{\text {biomass }}, \\
& Y_{\text {lutein }}(\mathrm{mg} / \mathrm{L})=C_{\text {lutein }} \times C_{\text {biomass }},
\end{aligned}
$$

where $P_{\text {biomass }}(\mathrm{g} / \mathrm{L} /$ day $), C_{\text {biomass }}(\mathrm{g} / \mathrm{L})$, and $C_{\text {lutein }}(\mathrm{mg} / \mathrm{g})$ are the biomass productivity, biomass concentration, and lutein content, respectively.

\section{Determination of protein accumulation}

Protein extraction was performed by using a protein extraction kit (BB-3131-1, BestBio, Shanghai, China). The measurement of protein content was performed by a Pierce ${ }^{\circledR}$ BCA protein assay kit (Thermo Scientific, Waltham, MA, USA). The protein productivity $\left(P_{\text {protein }}\right)$ and protein yield $\left(Y_{\text {protein }}\right)$ were measured by Eq. (6) and Eq. (7), respectively:

$$
\begin{aligned}
& P_{\text {protein }}(\mathrm{mg} / \mathrm{L} / \text { day })=C_{\text {protein }} \times P_{\text {biomass }}, \\
& Y_{\text {protein }}(\mathrm{mg} / \mathrm{L})=C_{\text {protein }} \times C_{\text {biomass }},
\end{aligned}
$$

where $P_{\text {biomass }}\left(\mathrm{g} / \mathrm{L} /\right.$ day), $C_{\text {biomass }}(\mathrm{g} / \mathrm{L})$, and $C_{\text {protein }}(\mathrm{mg} / \mathrm{g})$ are the biomass productivity, biomass concentration, and protein content, respectively.

The amino acid composition was determined as previously described (Tong et al. 2009) with modification. 
In short, $25 \mathrm{mg}$ freeze-dried microalga was mixed thoroughly with $10 \mathrm{~mL} 6 \mathrm{M} \mathrm{HCl}$ and three drops of phenol under nitrogen gas, and then hydrolyzed at $110{ }^{\circ} \mathrm{C}$ for $22 \mathrm{~h}$. The hydrolysate was cooled down to room temperature and filtered through a $0.22-\mu \mathrm{m}$ nylon filter. Subsequently, $1 \mathrm{~mL}$ of the hydrolysate was dried at $50{ }^{\circ} \mathrm{C}$ using a vacuum desiccator, dissolved in $1 \mathrm{~mL}$ water, and then dried again. Hydrolyzed protein was dissolved in $1 \mathrm{~mL}$ sodium citrate buffer ( $\mathrm{pH} 2.2$ ), and subsequently filtered through a $0.22-\mu \mathrm{m}$ nylon filter, which was used for the determination of amino acid content. An automatic amino acid analyzer (Biochrom $30+$ series, Biochrom, Cambridge, UK) was used to identify and quantify amino acids.

The essential amino acid index (EAAI) was determined as previously described (Sui et al. 2019) by Eq. (8):

$$
\mathrm{EAAI}=\sqrt[n]{\frac{\mathrm{aa} 1}{\mathrm{AA} 1} \times \frac{\mathrm{aa} 1}{\mathrm{AA} 1} \times \cdots \times \frac{\mathrm{aa} n}{\mathrm{AA} n}}
$$

where aa $n$ and AA $n$ are the proportion of a certain essential amino acid content in total protein content $(\mathrm{mg} / \mathrm{g})$ in the sample and FAO/WHO reference (Joint WHO/FAO/ UNU Expert Consultation 2007), respectively.

\section{Statistical analysis}

The results in tables and figures are presented as the means \pm standard deviation (SD) from three replicates. Origin v9.0 software (OriginLab Inc., Northampton, Mass, USA) was used to perform statistical analyses, and $p<0.05$ were considered statistically significant.

\section{Results and discussion}

\section{Co-production of lutein and protein in C. sorokiniana FZU60 under batch cultivation}

As shown in Fig. 1a, for batch cultivation, lutein and protein content increased with the increase in biomass when nitrogen was replete (day 0.5 to 1.56 ), while decreased after nitrogen was depleted (day 2.5). It was reported that xanthophyll and protein could only be accumulated in microalgae under the condition of sufficient nitrogen (Chen et al. 2015; Xie et al. 2013). This could be due to that algal cells absorb sufficient nitrogen for the biosynthesis of nitrogen-containing metabolites, such as protein. In addition, as a primary carotenoid, lutein is growth-related due to its function in light-harvesting and nonphotochemical quenching (NPQ) as a structural pigment bound to light-harvesting complex (LHC) associated proteins (Xie et al. 2021). Since nitrogen was a critical factor for cell growth (Lee et al. 2015; Plyusnina et al. 2020; Vello et al. 2018), both lutein and protein content increased concomitantly with cell growth under sufficient nitrogen. On the other hand, cells prefer to synthesize high-energy compounds, such as starch and lipid, under nitrogen deficiency conditions for energy store to overcome adverse environment (Siaut 2011). Thus, primary metabolites including protein and lutein may be degraded and shifted to those high-energy compounds when nitrogen was depleted.

To be noted, lutein and protein content reached 7.72 and $538.06 \mathrm{mg} / \mathrm{g}$ on day 1.563 , respectively. The newly isolated microalga C. sorokiniana FZU60 was deemed as a good candidate for lutein production (Xie et al. 2019a). Nevertheless, the production cost is considerably high attributed to the relatively low lutein content (normally lower than 1\%) in cell composition. Comprehensive utilization of algal biomass for multiple metabolites production can be used as an efficient way to improve the economic feasibility of lutein production (Ma et al. 2020a). This study found that the proportion of protein in cell composition was higher than $50 \%$, indicating that C. sorokiniana FZU60 is a good candidate for the co-production of lutein and protein.

The high protein content in C. sorokiniana FZU60 demonstrated that it could be used as a protein source for food or feed industry. Thus, it is essential to investigate the amino acid composition of C. sorokiniana FZU60, which is an important indicator for protein quality. As shown in Fig. 1b, the proportion of EAAs decreased from $37.37 \%$ to $36.18 \%$ with the consumption of nitrogen. EAAs cannot be biosynthesized by humans and have to be provided from food, thus EAAs proportion is a crucial marker for nutritional value (Muys et al. 2019). The EAAs proportion of $C$. sorokiniana FZU60 is in a relatively high level compared with some microalgae, such as Spirulina sp. (Prates et al. 2020). Concomitantly, EAAI dropped from 1.42 to 1.37 from day 0.5 to 2.5 . Protein with EAAI higher than one is considered as a good-quality nutrient for human consumption (Kent et al. 2015; Sui et al. 2019). The EAAI of C. sorokiniana FZU60 was superior to many microalgae, such as Nannochloropsis granulata (Tibbetts et al. 2015), Dunaliella salina (Sui et al. 2019), and many Chlorella and Spirulina species (Muys et al. 2019). In this study, lutein and protein content were highest at the onset of nitrogen depletion when EAAI was 1.40, indicating that protein can be a high-quantity and high-quality coproduct from lutein production in $C$. sorokiniana FZU60.

\section{Co-production of lutein and protein in C. sorokiniana FZU60 under semi-batch strategy}

In batch cultivation, with the increase in biomass concentration and the consumption of nutrients, the growth of algal cells would be retarded by the limitation of light and nutrients, and this problem could be effectively solved by semi-batch cultivation (Ferreira et al. 2011). Semi-batch cultivation can achieve stable and continuous 

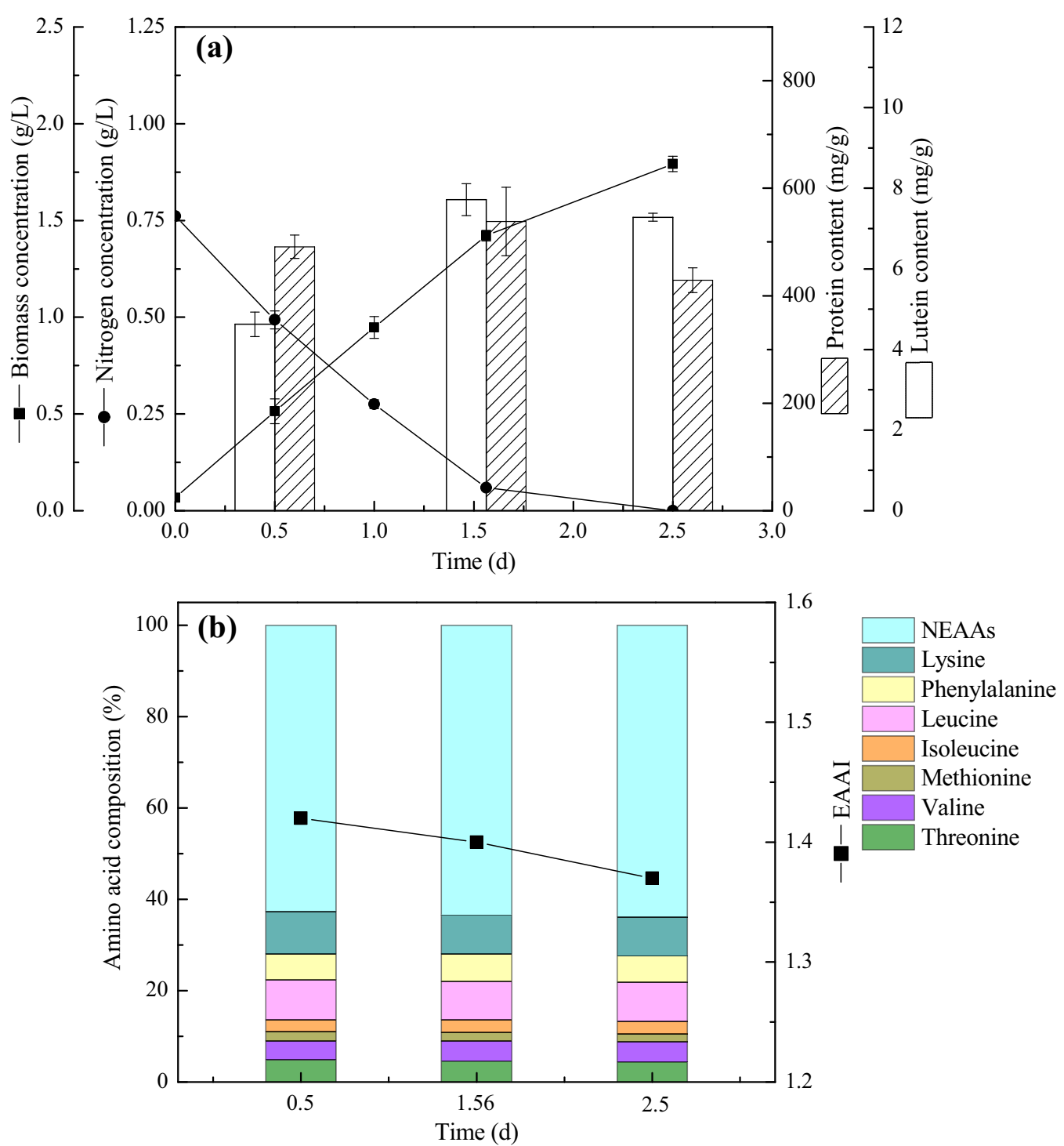

Fig. 1 Cell growth and lutein and protein accumulation of C. sorokiniana FZU60 under batch cultivation. a Biomass concentration, nitrogen concentration, lutein content, and protein content; $\mathbf{b}$ amino acid composition

production, and avoid restarting microalgae cultivation constantly, which can bring down contamination problem and production cost (Fuentes-Grünewald et al. 2015). In this study, three types of semi-batch cultivation strategies, with $25 \%, 50 \%$, and $75 \%$ microalgal culture replacement by fresh medium, respectively, were carried out to improve the co-production of lutein and protein in C. sorokiniana FZU60. As shown in Fig. 2, biomass concentration, lutein content, and protein content were relatively stable in each round, indicating that stable and continuous production was achieved by semi-batch cultivation. In addition, biomass, lutein, and protein productivity $(852.50,6.75$, and $478.70 \mathrm{mg} / \mathrm{L} /$ day, respectively) of semi-batch III were relatively superior to semi-batch I and II (Table 1). Similar results were found in C. sorokiniana MB-1-M12 that higher biomass and lutein productivity were obtained under $75 \%$ replacement in semi-batch cultivation, compared with that of $25 \%$ and 50\% replacement (Chen et al. 2019). This could be due to that an increase in initial inoculum size (low replacement) leads to a reduction in cell growth rate (Lu et al. 2012). Moreover, the content, productivity, and yield of lutein and protein in semi-batch III were close to that of batch cultivation, indicating that this semi-batch strategy can be used to co-produce lutein and protein stably and continuously. 

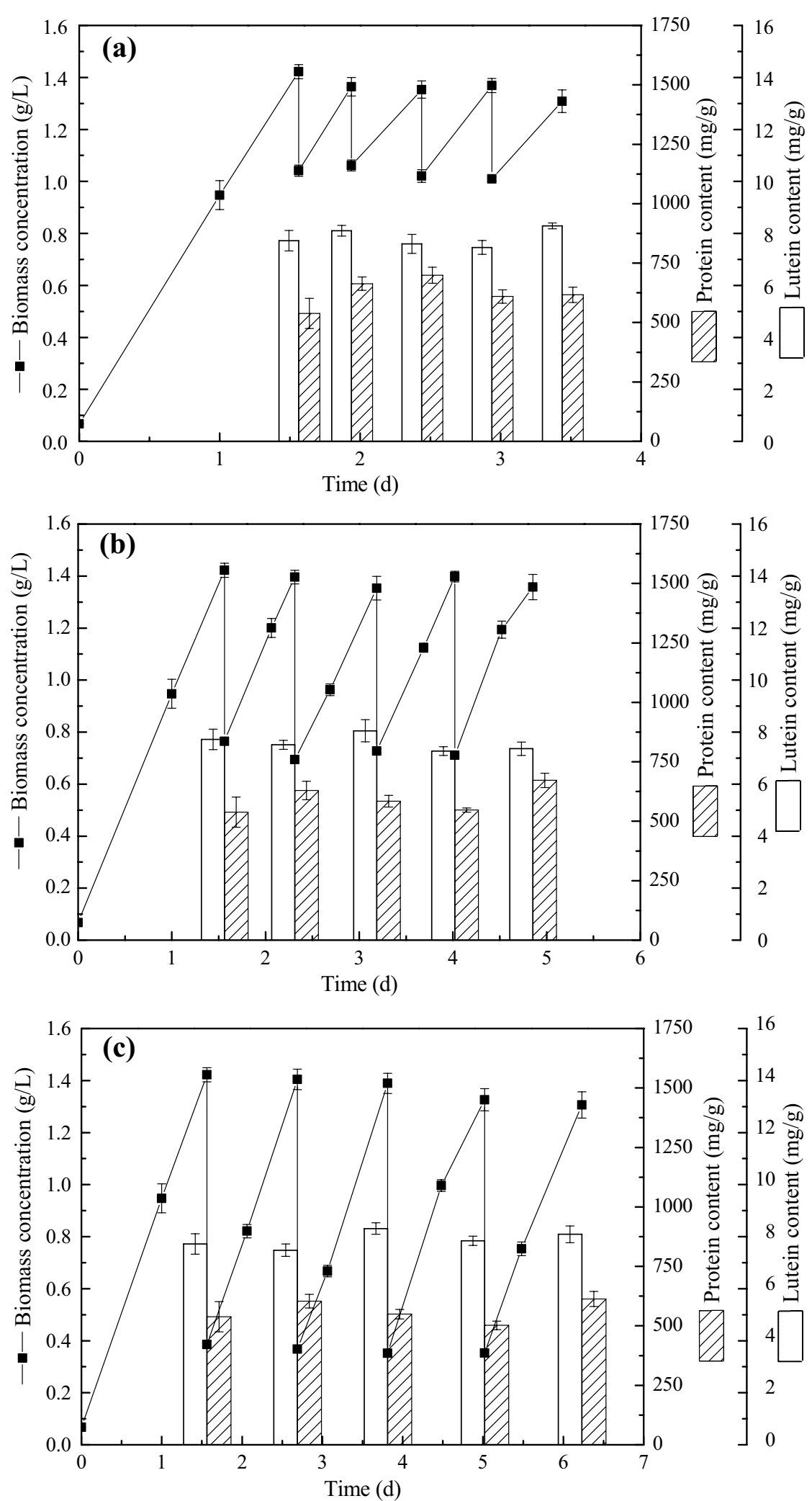

Fig. 2 Cell growth and lutein and protein accumulation of C. sorokiniana FZU60 under semi-batch cultivation strategies. a Semi-batch I strategy; b semi-batch II strategy; c semi-batch III strategy 
Table 1 Co-production of lutein and protein in C. sorokiniana FZU60 under different cultivation strategies

\begin{tabular}{lllllllr}
\hline $\begin{array}{l}\text { Cultivation } \\
\text { strategy }\end{array}$ & $\begin{array}{l}\text { Biomass } \\
\text { productivity } \\
\text { (mg/L/day) }\end{array}$ & $\begin{array}{l}\text { Lutein content } \\
\text { (mg/g) }\end{array}$ & $\begin{array}{l}\text { Lutein } \\
\text { productivity } \\
\text { (mg/L/day) }\end{array}$ & $\begin{array}{l}\text { Lutein yield } \\
\text { (mg/L) }\end{array}$ & $\begin{array}{l}\text { Protein content } \\
\text { (mg/g) }\end{array}$ & $\begin{array}{l}\text { Protein } \\
\text { productivity } \\
\text { (mg/L/day) }\end{array}$ & $\begin{array}{l}\text { Protein yield } \\
\text { (mg/L) }\end{array}$ \\
\hline Batch & $852.76 \pm 44.55$ & $7.72 \pm 0.40$ & $6.58 \pm 0.45$ & $10.99 \pm 0.77$ & $538.06 \pm 63.60$ & $458.83 \pm 23.97$ & $766.96 \pm 32.34$ \\
Semi-batch I & $718.09 \pm 134.24$ & $7.83 \pm 0.35$ & $5.67 \pm 1.09$ & $10.67 \pm 0.40$ & $625.47 \pm 60.98$ & $446.18 \pm 77.46$ & $851.55 \pm 30.42$ \\
Semi-batch II & $805.46 \pm 42.58$ & $7.58 \pm 0.31$ & $6.11 \pm 0.35$ & $10.50 \pm 0.43$ & $594.14 \pm 56.51$ & $478.14 \pm 44.24$ & $822.30 \pm 23.28$ \\
Semi-batch III & $852.50 \pm 55.06$ & $7.89 \pm 0.32$ & $6.75 \pm 0.51$ & $10.80 \pm 0.47$ & $561.27 \pm 46.67$ & $478.70 \pm 52.55$ & $768.59 \pm 20.76$ \\
Fed-batch I & $439.52 \pm 17.55$ & $8.96 \pm 0.26$ & $3.94 \pm 0.27$ & $15.57 \pm 2.90$ & $438.31 \pm 43.96$ & $192.26 \pm 11.63$ & $881.49 \pm 35.62$ \\
Fed-batch II & $611.20 \pm 19.94$ & $10.51 \pm 0.26$ & $6.43 \pm 0.37$ & $28.81 \pm 1.50$ & $479.59 \pm 9.14$ & $293.03 \pm 3.98$ & $1592.77 \pm 56.93$ \\
Two-stage & $1710.71 \pm 97.13$ & $8.74 \pm 0.40$ & $15.31 \pm 1.27$ & $22.93 \pm 1.87$ & $632.00 \pm 42.84$ & $1080.41 \pm 87.11$ & $1617.79 \pm 77.35$ \\
\hline
\end{tabular}

\section{Co-production of lutein and protein in C. sorokiniana FZU60 under fed-batch strategy}

Fed-batch cultivation is an easily operated strategy to avoid nutrient deficiency during microalgal cultivation. Nitrogen was considered as a crucial nutrient for lutein accumulation in microalgae, and lutein content significantly increased when feeding with relatively low concentration of nitrogen (Xie et al. 2013). Besides, as a nitrogen-containing compound, protein accumulation highly depends upon nitrogen. However, whether the other nutrients are required for lutein and protein accumulation during fed-batch cultivation needs to be further investigated. In view of this, two types of fed-batch strategies feeding with $0.25 \mathrm{~g} / \mathrm{L}$ sodium nitrate and $1 / 3$ modified BG11 medium, respectively, at the beginning of nitrogen deficiency, were carried out in this study. As shown in Fig. 3a, nitrogen consumption rate significantly slowed down after feeding with $0.25 \mathrm{~g} / \mathrm{L}$ sodium nitrate in fed-batch I. The nitrogen concentration was almost plateaued and kept at $0.16 \mathrm{~g} / \mathrm{L}$ after day 3.56 , indicating that it was not consumed anymore. However, nitrogen was regularly consumed in fed-batch II, and six times of 1/3 modified BG11 medium feeding were accomplished on day 7.56 (Fig. 3b). This could be due to that the lack of other nutrients reduced nitrogen consumption in microalgal cells (Osorio et al. 2019). It was reported that some algae could only maintain a normal nitrogen consumption rate under sufficient nutrient conditions, such as inorganic salts and trace elements (Crawford et al. 2003). Consistently, biomass concentration slowly increased and then levelled off in fed-batch I, while continually raised during all the cultivation period in fed-batch II. Medium with all components instead of sole nutrient was generally used as feeding nutrients in fed-batch strategy for improving cell growth and metabolites accumulation in microalgae, such as Chlamydomonas reinhardtii (Fields et al. 2018), Scenedesmus incrassatulus (Garcia-Canedo et al. 2016), and Phaeodactylum tricornutum (Chauton et al. 2013). This can avoid nutrient limitation since all components of the medium are consumed during the cultivation.

On the other hand, lutein content showed an upward trend with the time course of cultivation, followed by a decrease at the end. In contrast, protein content was highest at the beginning of cultivation, decreased and then levelled off afterwards. The increase in lutein content during the cultivation could be due to that the light intensity per algal cell decreased with the increase in biomass concentration. Thus, algal cells synthesized more lutein to capture light energy (Dineshkumar et al. 2016; Vaquero et al. 2014). Additionally, protein is a primary metabolite, which is growth related. Hence, protein content was at a high level at the primary stage of cultivation when cells grew extremely fast, and then decreased with the reduction in cell growth rate. To be noted, the maximal lutein content reached $10.51 \mathrm{mg} / \mathrm{g}$ with a high biomass concentration of $4.14 \mathrm{~g} / \mathrm{L}$ in fed-batch II, leading to super-high lutein and protein yield of 28.81 and $1592.77 \mathrm{mg} / \mathrm{L}$, respectively (Table 1 ). These results were significantly greater than that of batch cultivation, semibatch strategy, and fed-batch strategy.

\section{Co-production of lutein and protein in C. sorokiniana FZU60 under two-stage strategy}

In some cases, the trends of cell growth and metabolites accumulation are contradictory in microalgae. Thus, a two-stage strategy is normally explored to obtain high biomass and metabolite content separately. For example, in Haematococcus pluvialis, high cell density was initially achieved under sufficient nutrient and low light conditions, and then cells were exposed to stressed conditions, such as nitrogen starvation, high light, and salinity stress, to induce astaxanthin accumulation (Zhao et al. 2019). Similarly, a hetero-photoautotrophic two-stage strategy was used to obtain high biomass concentration and subsequently fucoxanthin accumulation in Nitzschia laevis (Lu et al. 2018). For most lutein-producing microalgae, cell growth rate 

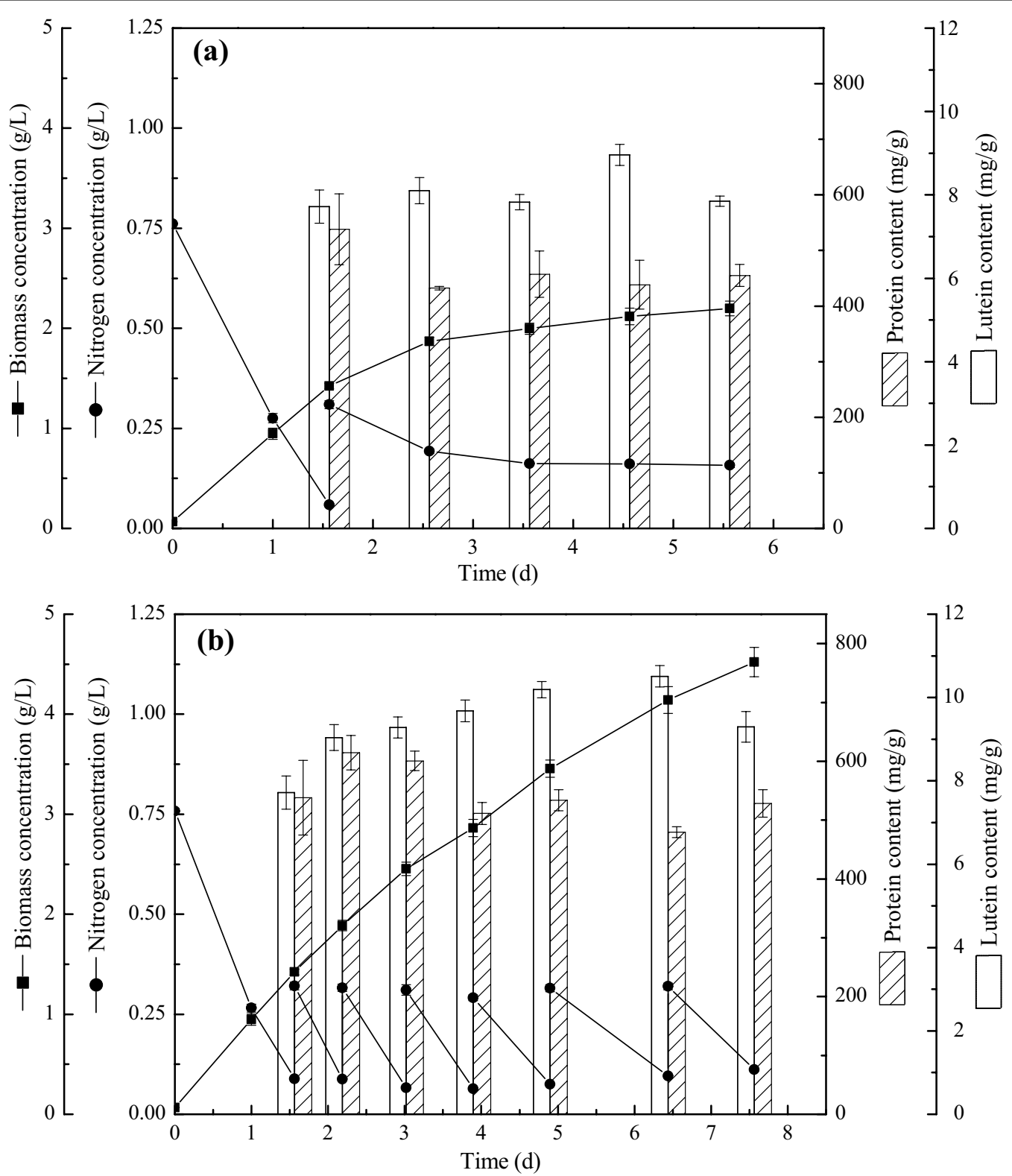

Fig. 3 Cell growth and lutein and protein accumulation of C. sorokiniana FZU60 under fed-batch cultivation strategies. a Fed-batch I strategy; b fed-batch II strategy

increases while lutein content reduces with an increase in light intensity (Ma et al. 2018; Xie et al. 2013), which is unbeneficial for lutein production. Similar result was found in the previous study that biomass productivity increased, while lutein content decreased, with the increase in light intensity from 250 to $800 \mu \mathrm{mol} /$ $\mathrm{m}^{2} / \mathrm{s}$, resulting in that peaked lutein productivity was obtained at $600 \mu \mathrm{mol} / \mathrm{m}^{2} / \mathrm{s}$ in C. sorokiniana FZU60 (Additional file 1: Figure S1). Thus, a two-stage strategy combining light intensity shift and semi-batch cultivation was explored to enhance lutein production in C. sorokiniana FZU60.

As shown in Fig. 4, biomass concentration, nitrogen consumption, lutein content, and protein content were at a relatively stable level for each round of cultivation. Noticeably, lutein and protein content significantly increased in stage II compared with that of stage I. This could be due to that the sudden drop in light intensity led to the synthesis of more LHC-associated proteins for the capture of light energy in microalgal cells. A similar 

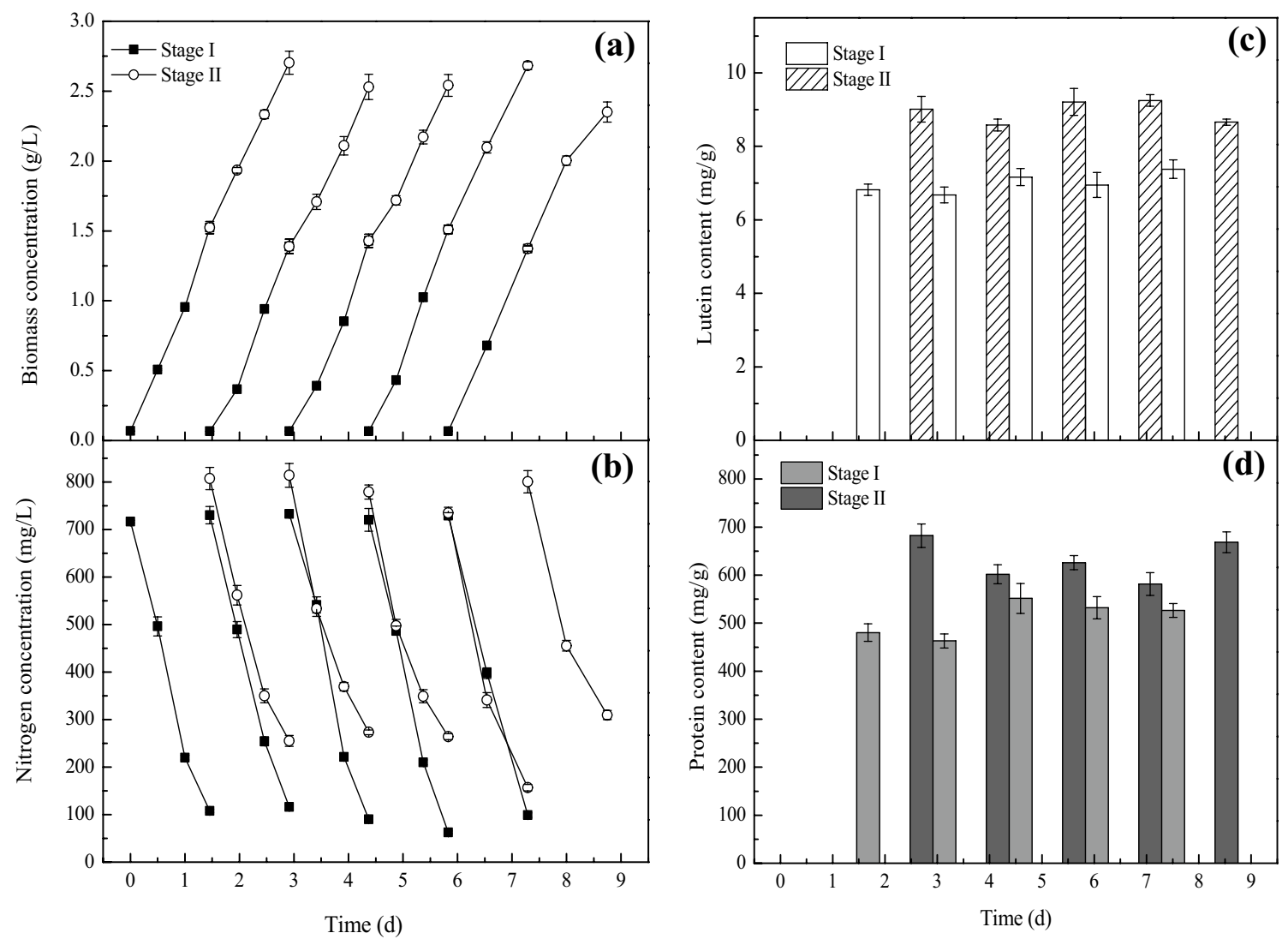

Fig. 4 Cell growth and lutein and protein accumulation of C. sorokiniana FZU60 under two-stage cultivation strategy. a Biomass concentration; b nitrogen concentration; $\mathbf{c}$ lutein content; $\mathbf{d}$ protein content

result was found in Scenedesmus obliquus FSP-3 that lutein content was significantly enhanced when light intensity shift from $300 \mu \mathrm{mol} / \mathrm{m}^{2} / \mathrm{s}$ to $75 \mu \mathrm{mol} / \mathrm{m}^{2} / \mathrm{s}$ (Ho et al. 2015). To be noted, high protein content $(632 \mathrm{mg} / \mathrm{g})$ was obtained in the two-stage strategy with a high level of lutein content $(8.74 \mathrm{mg} / \mathrm{g})$. Moreover, extremely high biomass productivity $(1710.71 \mathrm{mg} / \mathrm{L} /$ day $)$ was obtained in the two-stage strategy, leading to super-high lutein and protein productivity (15.31 and $1080.41 \mathrm{mg} / \mathrm{L} /$ day, respectively) (Table 1). Besides, compared with fed-batch II strategy, the shift of light intensity from high to low together with the shorter cultivation period indicated that the two-stage strategy was more energy-efficient. Herein, the two-stage strategy is high-efficiency for the co-production of lutein and protein.

\section{Comparison of different cultivation strategies}

Based on the above results, different cultivation strategies have their pros and cons. Semi-batch III strategy obtained similar content, productivity, and yield of lutein and protein as batch cultivation, which can be used for stable and continuous co-production of lutein and protein.
Fed-batch II, an easily operated strategy, achieved high lutein and protein yield, thus can be used for high-output co-production of lutein and protein. Besides, extremely high lutein and protein productivity were gained in the energy-efficient two-stage strategy with relatively high levels of lutein and protein yield. Hence, the two-stage strategy is a good option for high-efficiency co-production of lutein and protein.

In addition, carotenoid and amino acid composition need to be investigated, since they are important for the quality of lutein and protein. As shown in Fig. 5, carotenoid content was highest in fed-batch II strategy, followed by two-stage strategy, and it was lowest in batch cultivation. Lutein accounted for about $60 \%$ of the total carotenoids under different cultivation modes, and fedbatch II strategy obtained the highest lutein proportion (61.38\%). The highest EAAs proportion (38.61\%) was obtained in two-stage strategy, followed by fed-batch II strategy, and it was lowest in semi-batch III strategy. Consistently, the EAAI value was in the order of twostage $>$ fed-batch II $>$ batch $>$ semi-batch III. In conclusion, high-quality lutein and protein were obtained in 


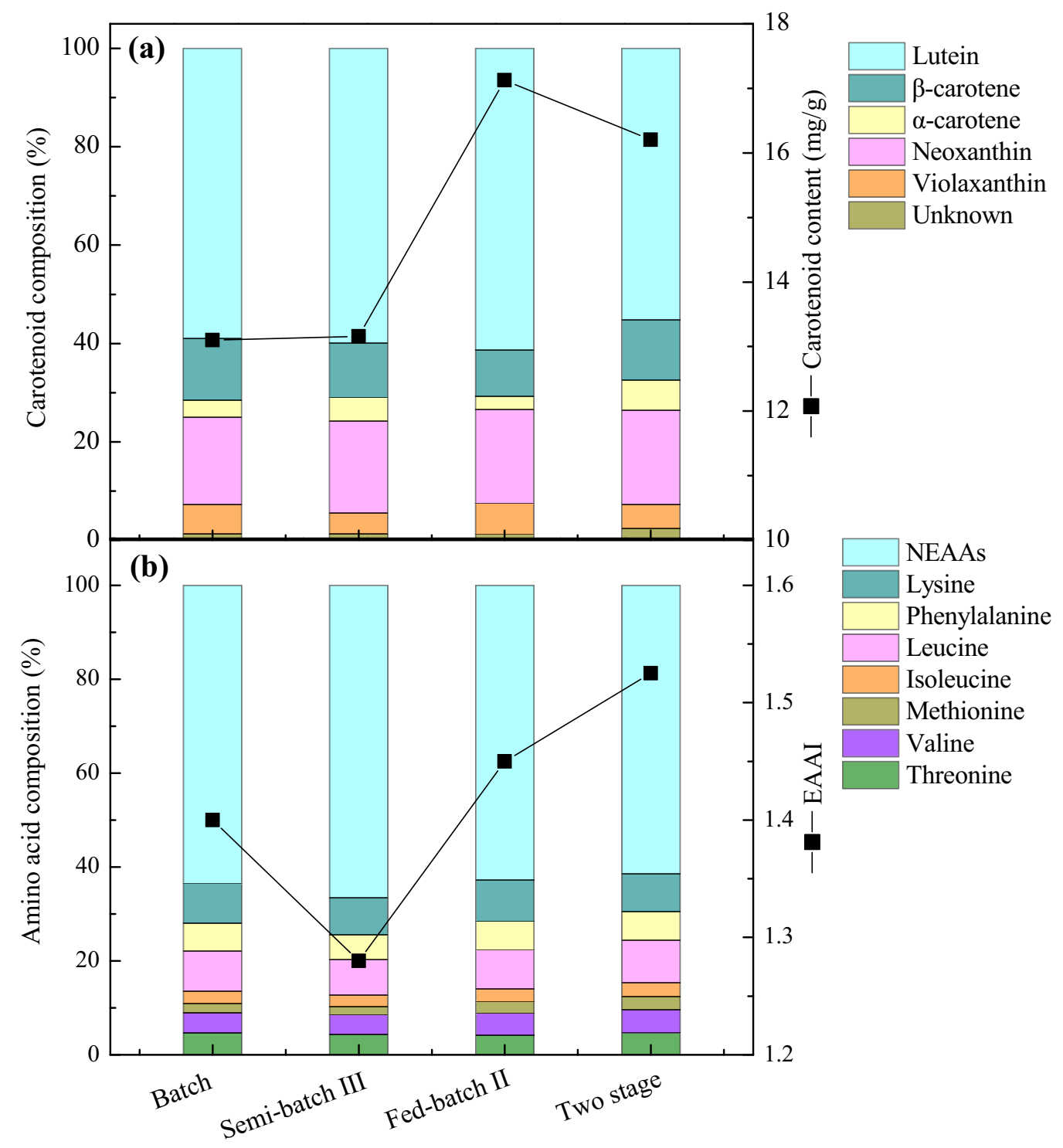

Fig. 5 Carotenoid and amino acid composition in C. sorokiniana FZU60 under different cultivation strategies. a Carotenoid composition; b amino acid composition

fed-batch II and two-stage strategy. Moreover, high yield or productivity of lutein and protein were achieved by these two strategies, respectively. Herein, fed-batch II and two-stage strategy are superior for the co-production of high-quality lutein and protein.

\section{Conclusions}

For batch cultivation, the highest lutein and protein content were obtained at the onset of nitrogen deficiency. Semi-batch III strategy can be used for stable and continuous co-production of lutein and protein. Fed-batch II strategy is advantageous for high-output co-production of lutein and protein with super-high yield. Additionally, two-stage strategy is a good option for high-efficiency co-production of lutein and protein with extremely high productivity. Moreover, high-quality lutein and protein were obtained under fed-batch II and two-stage strategy, indicating that these two strategies are superior for the co-production of lutein and protein in C. sorokiniana FZU60. This study provides new insight into the improvement of economic feasibility of lutein production by co-producing high-value protein. 


\section{Abbreviations}

AMD: Age-related macular degeneration; DHA: Docosahexaenoic acid; EAAs: Essential amino acids; EAAl: Essential amino acid index; EPA: Eicosapentaenoic acid; LHC: Light-harvesting complex; NEEAs: Nonessential amino acids; NPQ: Nonphotochemical quenching; SD: Standard deviation; SDA: Stearidonic acid.

\section{Supplementary Information}

The online version contains supplementary material available at https://doi. org/10.1186/s40643-021-00436-9.

Additional file 1: Figure S1. Effect of light intensity on cell growth and lutein accumulation. (a) Biomass productivity and maximum specific growth rate; (b) lutein content and productivity. Figure S2. Effect of temperature on cell growth and lutein accumulation. (a) Biomass productivity and maximum specific growth rate; (b) lutein content and productivity.

\section{Acknowledgements}

Not applicable.

\section{Authors' contributions}

YX designed and supervised the experiments; RM and ZZ analyzed the data and wrote the manuscript; ZT performed the experiments; SH, XS, LL and JC reviewed and edited the manuscript. All authors read and approved the final manuscript.

\section{Funding}

This study was financially supported by the Demonstration Project for Innovative Development of Fuzhou's Marine Economy during the 13th Five-Year Plan, China (Nos. FZHJ15 and FZHJ04), the Natural Science Foundation of Fujian Province, China (No. 2020J01484), and the Education and Research Project for Middle-Aged and Young Teachers of the Education Department of Fujian Province, China (No. JAT200036).

\section{Availability of data and materials}

The datasets used and/or analyzed during the current study are available from the corresponding author on reasonable request.

\section{Declarations}

Ethical approval and consent to participate Not applicable.

\section{Consent for publication}

Not applicable.

\section{Competing interests}

The authors declare that they have no competing interests.

\begin{abstract}
Author details
${ }^{1}$ Technical Innovation Service Platform for High Value and High Quality Utilization of Marine Organism, Fuzhou University, Fuzhou 350108, China. ${ }^{2}$ Fujian Engineering and Technology Research Center for Comprehensive Utilization of Marine Products Waste, Fuzhou University, Fuzhou 350108, China. ${ }^{3}$ Fuzhou Industrial Technology Innovation Center for High Value Utilization of Marine Products, Fuzhou University, Fuzhou 350108, China. ${ }^{4}$ State Key Laboratory of Urban Water Resource and Environment, School of Environment, Harbin Institute of Technology, Harbin 150090, China.
\end{abstract}

Received: 15 July 2021 Accepted: 23 August 2021

Published online: 30 August 2021

\section{References}

Becker EW (2007) Micro-algae as a source of protein. Biotechnol Adv 25:207-210
Bin Azmi AA, Chew KW, Chia WY, Mubashir M, Sankaran R, Lam MK, Lim JW, Ho YC, Show PL (2021) Green bioprocessing of protein from Chlorella vulgaris microalgae towards circular bioeconomy. Bioresour Technol 333:12519

Chauton MS, Olsen Y, Vadstein O (2013) Biomass production from the microalga Phaeodactylum tricornutum: Nutrient stress and chemical composition in exponential fed-batch cultures. Biomass Bioenergy 58:87-94

Chen C-Y, Lee P-J, Tan CH, Lo Y-C, Huang C-C, Show PL, Lin C-H, Chang J-S (2015) Improving protein production of indigenous microalga Chlorella vulgaris FSP-E by photobioreactor design and cultivation strategies. Bioresour Technol 10:905-914

Chen JH, Chen CY, Hasunuma T, Kondo A, Chang CH, Ng IS, Chang JS (2019) Enhancing lutein production with mixotrophic cultivation of Chlorella sorokiniana MB-1-M12 using different bioprocess operation strategies. Bioresour Technol 278:17-25

Crawford DW, Lipsen MS, Purdie DA, Lohan MC, Statham PJ, Whitney FA, Putland JN, Johnson WK, Sutherland N, Peterson TD (2003) Influence of zinc and iron enrichments on phytoplankton growth in the northeastern subarctic Pacific. Limnol Oceanogr 48:1583-1600

Dineshkumar R, Subramanian G, Dash SK, Sen R (2016) Development of an optimal light-feeding strategy coupled with semi-continuous reactor operation for simultaneous improvement of microalgal photosynthetic efficiency, lutein production and $\mathrm{CO}_{2}$ sequestration. Biochem Eng J 113:47-56

Dixon C, Wilken LR (2018) Green microalgae biomolecule separations and recovery. Bioresour Bioprocess 5:14

Ferreira M, Seixas P, Coutinho P, Fábregas J, Otero A (2011) Effect of the nutritional status of semi-continuous microalgal cultures on the productivity and biochemical composition of Brachionus plicatilis. Mar Biotechnol 13:1074-1085

Fields FJ, Ostrand JT, Mayfield SP (2018) Fed-batch mixotrophic cultivation of Chlamydomonas reinhardtii for high-density cultures. Algal Res 33:109-117

Fuentes-Grünewald C, Bayliss C, Zanain M, Pooley C, Scolamacchia M, Silkina A (2015) Evaluation of batch and semi-continuous culture of Porphyridium purpureum in a photobioreactor in high latitudes using Fourier Transform Infrared spectroscopy for monitoring biomass composition and metabolites production. Bioresour Technol 189:357-363

Garcia-Canedo JC, Cristiani-Urbina E, Flores-Ortiz CM, Ponce-Noyola T, EsparzaGarcia F, Canizares-Villanueva RO (2016) Batch and fed-batch culture of Scenedesmus incrassatulus: effect over biomass, carotenoid profile and concentration, photosynthetic efficiency and non-photochemical quenching. Algal Res 13:41-52

Geada P, Moreira C, Silva M, Nunes R, Madureira L, Rocha CMR, Pereira RN, Vicente AA, Teixeira JA (2021) Algal proteins: production strategies and nutritional and functional properties. Bioresour Technol 332:125125

Ho SH, Chen CNN, Lai YY, Lu WB, Chang JS (2014) Exploring the high lipid production potential of a thermotolerant microalga using statistical optimization and semi-continuous cultivation. Bioresour Technol 163:128-135

Ho SH, Xie YP, Chan MC, Liu CC, Chen CY, Lee DJ, Huang CC, Chang JS (2015) Effects of nitrogen source availability and bioreactor operating strategies on lutein production with Scenedesmus obliquus FSP-3. Bioresour Technol 184:131-138

Joint WHO/FAO/UNU Expert Consultation (2007) Protein and amino acid requirements in human nutrition introduction. In: Haden A (ed) World Health Organization technical report, vol 935. WHO Press, Geneva, p 150

Kent M, Welladsen HM, Mangott A, Li Y, Kumar S (2015) Nutritional evaluation of australian microalgae as potential human health supplements. PLoS ONE 10:e0118985

Khoo KS, Chong YM, Chang WS, Yap JM, Foo SC, Khoiroh I, Lau PL, Chew KW, Ooi CW, Show PL (2021) Permeabilization of Chlorella sorokiniana and extraction of lutein by distillable $\mathrm{CO}_{2}$-based alkyl carbamate ionic liquids. Sep Purif Technol 256:117471

Koyande AK, Tanzil V, Dharan HM, Subramaniam M, Robert RN, Lau PL, Khoiroh I, Show PL (2020) Integration of osmotic shock assisted liquid biphasic system for protein extraction from microalgae Chlorella vulgaris. Biochem Eng J 157:107532

Lee E, Jalalizadeh M, Zhang Q (2015) Growth kinetic models for microalgae cultivation: A review. Algal Res 12:497-512

Levasseur W, Perre P, Pozzobon V (2020) A review of high value-added molecules production by microalgae in light of the classification. Biotechnol Adv 41:107545 
Li YL, Sun H, Wu T, Fu YL, He YJ, Mao XM, Chen F (2019) Storage carbon metabolism of Isochrysis zhangjiangensis under different light intensities and its application for co-production of fucoxanthin and stearidonic acid. Bioresour Technol 282:94-102

Lin JH, Lee DJ, Chang JS (2015) Lutein production from biomass: Marigold flowers versus microalgae. Bioresour Technol 184:421-428

Lu SH, Wang JX, Niu YH, Yang J, Zhou J, Yuan YJ (2012) Metabolic profiling reveals growth related FAME productivity and quality of Chlorella sorokiniana with different inoculum sizes. Biotechnol Bioeng 109:1651-1662

Lu X, Sun H, Zhao WY, Cheng KW, Chen F, Liu B (2018) A hetero-photoautotrophic two-stage cultivation process for production of fucoxanthin by the marine diatom Nitzschia laevis. Mar Drugs 16:219

Lu K, Zhao X, Ho SH, Ma R, Xie Y, Chen J (2019) Biorefining and the functional properties of proteins from lipid and pigment extract residue of Chlorella pyrenoidosa. Mar Drugs 17:454

Ma R, Zhao X, Xie Y, Ho SH, Chen J (2018) Enhancing lutein productivity of Chlamydomonas sp. via high-intensity light exposure with corresponding carotenogenic genes expression profiles. Bioresour Technol 275:416-420

Ma R, Wang B, Chua ET, Zhao X, Lu K, Ho SH, Shi X, Liu L, Xie Y, Lu Y, Chen J (2020a) Comprehensive utilization of marine microalgae for enhanced co-production of multiple compounds. Mar Drugs 18:467

Ma R, Zhao X, Ho SH, Shi X, Liu L, Xie Y, Chen J, Lu Y (2020b) Co-production of lutein and fatty acid in microalga Chlamydomonas sp. JSC4 in response to different temperatures with gene expression profiles. Algal Res 47:101821

Maximize Market Research PVT. LTD (2020) Global lutein market industry analysis and forecast (2020-2027) — by form, by source, by production process, by application and by geography. https://www.maximizemarketr esearch.com/market-report/lutein-market/661/. Accessed Jan 2020

Muys M, Sui YX, Schwaiger B, Lesueur C, Vandenheuvel D, Vermeir P, Vlaeminck SE (2019) High variability in nutritional value and safety of commercially available Chlorella and Spirulina biomass indicates the need for smart production strategies. Bioresour Technol 275:247-257

Osorio JHM, Pinto G, Pollio A, Frunzo L, Lens PNL, Esposito G (2019) Start-up of a nutrient removal system using Scenedesmus vacuolatus and Chlorella vulgaris biofilms. Bioresour Bioprocess 6:27

Plyusnina TY, Khruschev SS, Degtereva NS, Konyukhov IV, Solovchenko AE, Kouzmanova M, Goltsev VN, Riznichenko GY, Rubin AB (2020) Special issue in honour of Prof. Reto J. Strasser-gradual changes in the photosynthetic apparatus triggered by nitrogen depletion during microalgae cultivation in photobioreactor. Photosynthetica 58:443-451

Prates DD, Duarte JH, Vendruscolo RG, Wagner R, Ballus CA, Oliveira WD, Godoy HT, Barcia MT, de Morais MG, Radmann EM, Costa JAV (2020) Role of light emitting diode (LED) wavelengths on increase of protein productivity and free amino acid profile of Spirulina sp. cultures. Bioresour Technol $306: 123184$

Siaut M (2011) Oil accumulation in the model green alga Chlamydomonas reinhardtii: characterization, variability between common laboratory strains and relationship with starch reserves. BMC Biotechnol 11:7

Soto-Sierra L, Wilken LR, Dixon CK (2020) Aqueous enzymatic protein and lipid release from the microalgae Chlamydomonas reinhardtii. Bioresour Bioprocess 7:46
Sui Y, Muys M, Van de Waal DB, D'Adamo S, Vermeir P, Fernandes TV, Vlaeminck SE (2019) Enhancement of co-production of nutritional protein and carotenoids in Dunaliella salina using a two-phase cultivation assisted by nitrogen level and light intensity. Bioresour Technol 287:121398

Sun Z, Li T, Zhou ZG, Jiang Y (2016) Microalgae as a source of lutein: chemistry, biosynthesis, and carotenogenesis. Adv Biochem Eng Biotechnol 153:37-58

Sun Z, Wang X, Liu J (2019) Screening of Isochrysis strains for simultaneous production of docosahexaenoic acid and fucoxanthin. Algal Res 41:101545

Tachihana S, Nagao N, Katayama T, Hirahara M, Yusoff FM, Banerjee S, Shariff M, Kurosawa N, Toda T, Furuya K (2020) High productivity of eicosapentaenoic acid and fucoxanthin by a marine diatom Chaetoceros gracilis in a semi-continuous culture. Front Bioeng Biotechnol 8:602721

Tibbetts SM, Bjornsson WJ, McGinn PJ (2015) Biochemical composition and amino acid profiles of Nannochloropsis granulata algal biomass before and after supercritical fluid $\mathrm{CO}_{2}$ extraction at two processing temperatures. Anim Feed Sci Technol 204:62-71

Tong Z, Chi Z, Sheng J (2009) A highly thermosensitive and permeable mutant of the marine yeast Cryptococcus aureus G7a potentially useful for singlecell protein production and its nutritive components. Mar Biotechnol $11: 280-286$

Vaquero I, Mogedas B, Ruiz-Dominguez MC, Vega JM, Vilchez C (2014) Lightmediated lutein enrichment of an acid environment microalga. Algal Res 6:70-77

Vello V, Chu W-L, Lim P-E, Majid NA, Phang S-M (2018) Metabolomic profiles of tropical Chlorella species in response to physiological changes during nitrogen deprivation. J Appl Phycol 30:3131-3151

Xie Y, Ho SH, Chen CN, Chen CY, Ng IS, Jing KJ, Chang JS, Lu Y (2013) Phototrophic cultivation of a thermo-tolerant Desmodesmus sp. for lutein production: Effects of nitrate concentration, light intensity and fed-batch operation. Bioresour Technol 144:435-444

Xie Y, Li J, Ma R, Ho SH, Shi X, Liu L, Chen J (2019a) Bioprocess operation strategies with mixotrophy/photoinduction to enhance lutein production of microalga Chlorella sorokiniana FZU60. Bioresour Technol 290:121798

Xie Y, Lu K, Zhao X, Ma R, Chen J, Ho SH (2019b) Manipulating nutritional conditions and salinity-gradient stress for enhanced lutein production in marine microalga Chlamydomonas sp. Biotechnol J 14:1800380

Xie Y, Xiong X, Chen S (2021) Challenges and potential in increasing lutein content in microalgae. Microorganisms 9:1068

Zhao YT, Yue CC, Geng SX, Ning DL, Ma T, Yu XY (2019) Role of media composition in biomass and astaxanthin production of Haematococcus pluvialis under two-stage cultivation. Bioprocess Biosyst Eng 42:593-602

Zhao TT, Liu MX, Zhao TT, Chen AL, Zhang L, Liu H, Ding K, Xiao PY (2021) Enhancement of lipid productivity in Chlorella pyrenoidosa by collecting cells at the maximum cell number in a two-stage culture strategy. Algal Res 55:102278

\section{Publisher's Note}

Springer Nature remains neutral with regard to jurisdictional claims in published maps and institutional affiliations.

\section{Submit your manuscript to a SpringerOpen ${ }^{\circ}$ journal and benefit from:}

- Convenient online submission

- Rigorous peer review

- Open access: articles freely available online

- High visibility within the field

- Retaining the copyright to your article

Submit your next manuscript at springeropen.com 